\title{
Gambaran Histologi Ginjal Tikus Wistar Yang Terpapar MSG Setelah Perlakuan Diberikan Jus Tomat Dan Diberhentikan Perlakuan Saja

\author{
(Study Literature)
}

Yeti Eka Sispita Sari ${ }^{1}$

Prodi D3 Teknologi Laboratorium Medik, FIK, Universitas Muhammadiyah Surabaya

1)yetyikas.s@gmail.com

Tanggal Submit:
2 Mei 2018
Tanggal Review:
21 Mei 2018
Tanggal Publish
Online:
25 Mei 2018

\begin{abstract}
MSG causes many side effects on the body, but MSG has long been used as a food flavor that can bring tastes (umami) and play a role in strengthening the taste. The chemical structure of MSG is no different from Glutamic Acid (glutamate), it is one of the 20 amino acids that make up proteins in the body. So the use of MSG needs to be discontinued to prevent kidney damage due to continued consumption of MSG, two research were conducted to determine the effect of discharging of MSG consumption by being given tomato juice (1) and discharged without treatment (2), the second study was seen from the histology picture of rats wistar mouse.

Methods were experimental with post test only control group design. The research (1) used 15 wistar rats divided into three groups: group I without treatment (pellet AD II and drinking water), group II was given MSG for 14 days and group III was given tomato juice and MSG for 14 days. The study (2) used 27 rats divided by 9 groups. The sample is selected by simple random sampling method. The mice were then gradually turned off on the 29th, 43rd and 57th days. There was no significant difference in mean number of normal and damaged proximal tubules in all treatment groups. The renal histologic features in the treatment group I (MSG) and the treatment group II (MSG and tomato juice) showed normal glomeruli, tubular epithelial tubules, and lumen tubular narrowing whereas in mice discharged without treatment there was no apparent difference between the two MSG Giving groups damage to proximal tubules and renal corpusculum and regeneration after 14 days of discontinuation of MSG. Conclusions from these two experiments occurred damage to the renal tubules
\end{abstract}

Keywords: MSG, Kidney, Wistar Rat

PENDAHULUAN

Semua efek berbahaya MSG

menjadi tidak mengejutkan lagi bagi

kebanyakan orang, walau telah terbukti banyak zat aditif (zat tambahan) pada makanan yang umumnya kita makan, ternyata telah ditemukan dampak biologinya 
terhadap kesehatan kita, tapi anehnya justru kita tidak mau mengantisipasinya. Hal ini sangat mungkin karena efeknya cenderung lama bahkan menahun, namun dengan pasti, terbukti dari pasien dan penderitanya yang selalu bertambah dan semakin bertambah dari tahun ke tahun, seperti yang ditunjukkan dalam sebuah studi baru-baru ini ketika menyelidiki efek neurologis (syaraf) akibat dari MSG dan aspartam ( penelitian Abu-Taweel GM et al, 2014 ).

Semua hasil penelitian oleh para ahli-ahli farmasi dan laboratorium di dunia selama beberapa tahun terakhir tentang dampak MSG bagi tubuh kita sudah dibukukan bahkan banyak terdapat di internet, namun hasil penelitian mereka seakan "ditelan" oleh Bumi dan tak diangkat kepermukaan. FDA menganggap label seperti "Tanpa MSG" atau "Tanpa Tambahan MSG" menyesatkan, jika makanan yang mengandung bahan MSG merupakan sumber glutamat bebas, seperti protein terhidrolisis. Pada tahun 1993, FDA mengusulkan penambahan frase "(mengandung glutamat)" pada nama umum atau biasa dari hidrolisat protein tertentu yang mengandung sejumlah besar glutamat.

Menurut United State Renal Data System (2013) di Amerika Serikat prevalensi penyakit gagal ginjal kronik meningkat 20-25 \% setiap tahun. Diperkirakan lebih dari 20 juta (lebih dari 10\%) orang dewasa di Amerika Serikat mengalami penyakit ginjal kronik per tahun. Kasus penyakit ginjal di dunia per tahun meningkat sebanyak lebih dari $50 \%$. Perkiraan WHO (2012) angka harapan hidup penduduk Indonesia mencapai 71 tahun dan pada tahun yang sama WHO memperkirakan angka kematian disebabkan oleh penyakit kronis di Indonesia mencapai 54\% dari seluruh penyebab kematian. Salah satu penyakit kronis yang angka kejadiannya diperkirakan meningkat tiap tahun adalah penyakit gagal ginjal kronik. Data di Indonesia menunjukkan peningkatan insidensi penderita yang menjalani terapi hemodialisis dari tahun 2007 sampai 2012 yakni 6862 pada tahun 2007, tahun 2008 sebanyak 7328penderita, tahun 2009 sebanyak 12.900 penderita, 2010 sebanyak 14.833 
penderita, 2011 sebanyak 22.304

penderita dan 2012 sebanyak 28.782

penderita (Indonesian Renal

Registry,2013)

Struktur Ginjal dan Histologis Ginjal Lengkung Henle adalah struktur berbentuk $U$ terdiri atas ruas tebal descenden dengan struktur yang sangat mirip tubulus kontortus proksimal, ruas tipis descenden, ruas tipis ascenden, dan ruas tebal ascenden, yang strukturnya sangat mirip dengan tubulus kontortus distal. Lebih kurang sepertujuh dari semua nefron terletak dekat batas korteks- medula yang disebut nefron jukstamedula. Nefron lainnya disebut nefron kortikal. Semua nefron turut serta dalam proses filtrasi, absorpsi dan sekresi. Ruas ascenden lengkung Henle yang menerobos korteks, struktur histologisnya tetap terpelihara tetapi menjadi berkelok-kelok dan disebut tubulus kontortus distal, yaitu bagian terakhir nefron yang dilapisi oleh epitel selapis kuboid (Bernike, 2008). Potongan histologis tubulus kontortus proksimal dan distal, terdapat dalam korteks dan mempunyai epitel kubis. Perbedaan antara keduanya didasarkan pada sifat-sifat berikut: sel-sel tubulus proksimal lebih besar, mempunyai brush border, dan lebih asidofil karena banyak mengandung mitokondria. Lumen tubulus distal lebih besar, dan karena sel-sel tubulus distal lebih pendek dan lebih kecil dari pada sel-sel tubulus proksimal, pada potongan yang sama dinding tubulus distal terlihat lebih banyak sel dan lebih banyak inti. Selsel tubulus distal kurang asidofil dari pada sel-sel tubulus proksimal, dan tidak menunjukkan brush border atau mikrovili yang banyak (Junqueira \& Carneiro, 1991).

\section{METODE PENELITIAN}

Penelitian (1) menggunakan metode eksperi-mental dengan post test only control group design. Sampel yang digunakan Ialah 15 ekor tikus wistar yang akan dibagi menjadi tiga kelompok: kelompok I tanpa perlakuan; kelompok II diberikan MSG dengan dosis 4 gr selama 14 hari; dan kelompok III diberikan jus tomat dengan dosis 3 $\mathrm{ml}$ dan MSG dengan dosis $4 \mathrm{gr}$ selama 14 hari. Terminasi dilakukan pada hari ke 15. Setelah diterminasi, ginjal tikus difiksasi dan dibuat 
preparat Histologi dengan potongan

melintang dan dilakukan pengecatan HE.

Perlakuan pada penelitian (2) adalah pemberian MSG dengan dosis sebesar 5mg/gBB tikus/hari yang dilarutkan dalam 1,5 ml Akuadest. Pemberian MSG dilakukan secara oral menggunakan sonde. MSG

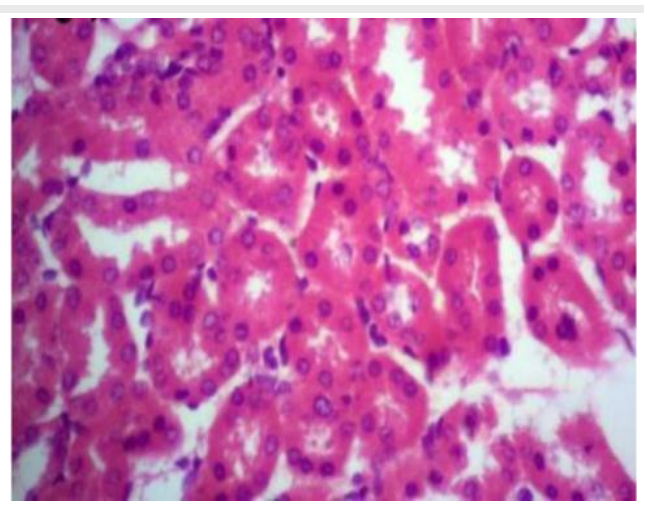

Gambar 1. Gambaran histologik ginjal tanpa dengan perlakuan dengan pembesaran $10 \times 100$

diberikan tiap hari selama 28 hari. Setelah diberi perlakuan selama 28 hari, perlakuan kemudian dihentikan selama 1 hari, 14 hari, dan 28 hari sesuai kelompok perlakuan. Pada hari ke-2, hari ke-15, dan hari ke-29 dilakukan pengambilan organ ginjal tikus untuk pembuatan preparat. Ginjal tikus kemudian dibuat preparat histologis dengan potongan melintang dan dilakukan pengecatan HE.

\section{HASIL DAN PEMBAHASAN}

Pada kelompok tanpa perlakuan atau hanya diberikan air minum dan pelet, menunjukkan gambaran histologik normal (Gambar 1).

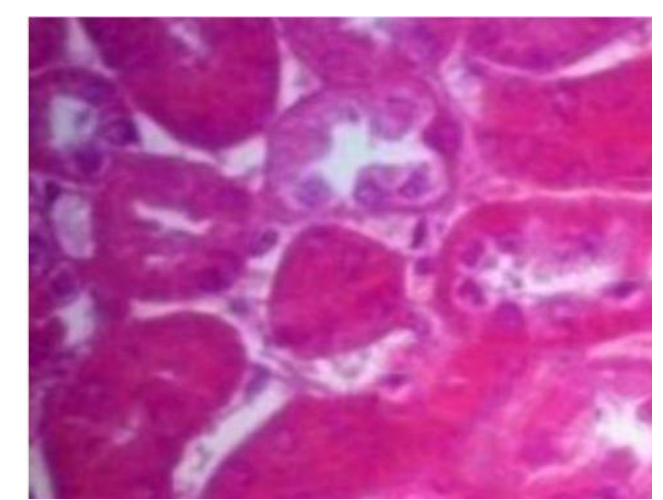

Gambar 2. Gambaran histologik ginjal dengan perlakuan pemberian MSG dengan pembesaran 10x100

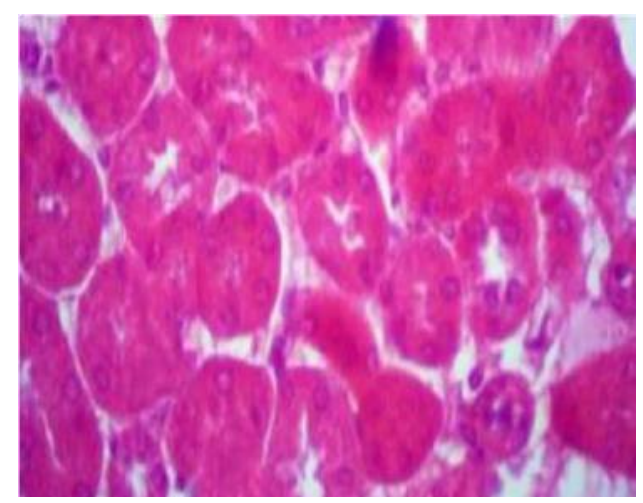

Gambar 3. Gambaran histologik ginjal dengan pemberian MSG dan jus tomat dengan pembesaran 10x100. 
The Joumal Of Muhammadiyah Medical Laboratory Technologist

Vol. 1No.2November 2018

p-ISSN: 2597-3681 e-ISSN:26142805

Kelompok dengan pemberian

MSG dan jus tomat menunjukkan gambaran histologik berupa glomerulus normal, pembengkakan epitel tubulus, dan penyempitan lumen.

Gambaran mikroskopis kelompok perlakuan I dan kelompok perlakuan II ditemukan glomerulus normal, perubahan pada ginjal, epitel tubulus proksimal yang mengalami pembengkakan dan penyempitan lumen. Gambaran mikroskopis berupa sel-sel epitel tubulus proksimal yang membengkak dengan sitoplasma granuler karena terjadi pergeseran air ekstraseluler ke dalam sel. Pergeseran cairan ini terjadi

karena adanya toksin yang
menyebabkan perubahan muatan listrik pada permukaan sel epitel tubulus, perubahan transpor aktif ion dan asam organik, dan kemampuan mengkonsentrasikan dari ginjal yang akhirnya mengakibatkan tubulus rusak, aliran menurun. Gambaran pembengkakan sel ini disebut degenerasi albuminosa atau degenerasi parenkimatosa atau cloudy swelling (bengkak keruh), yang merupakan bentuk degenerasi yang paling ringan serta bersifat reversibel. Hal inilah yang mungkin menyebabkan lumen tubulus proksimal mengalami penyempitan hingga menutup. 

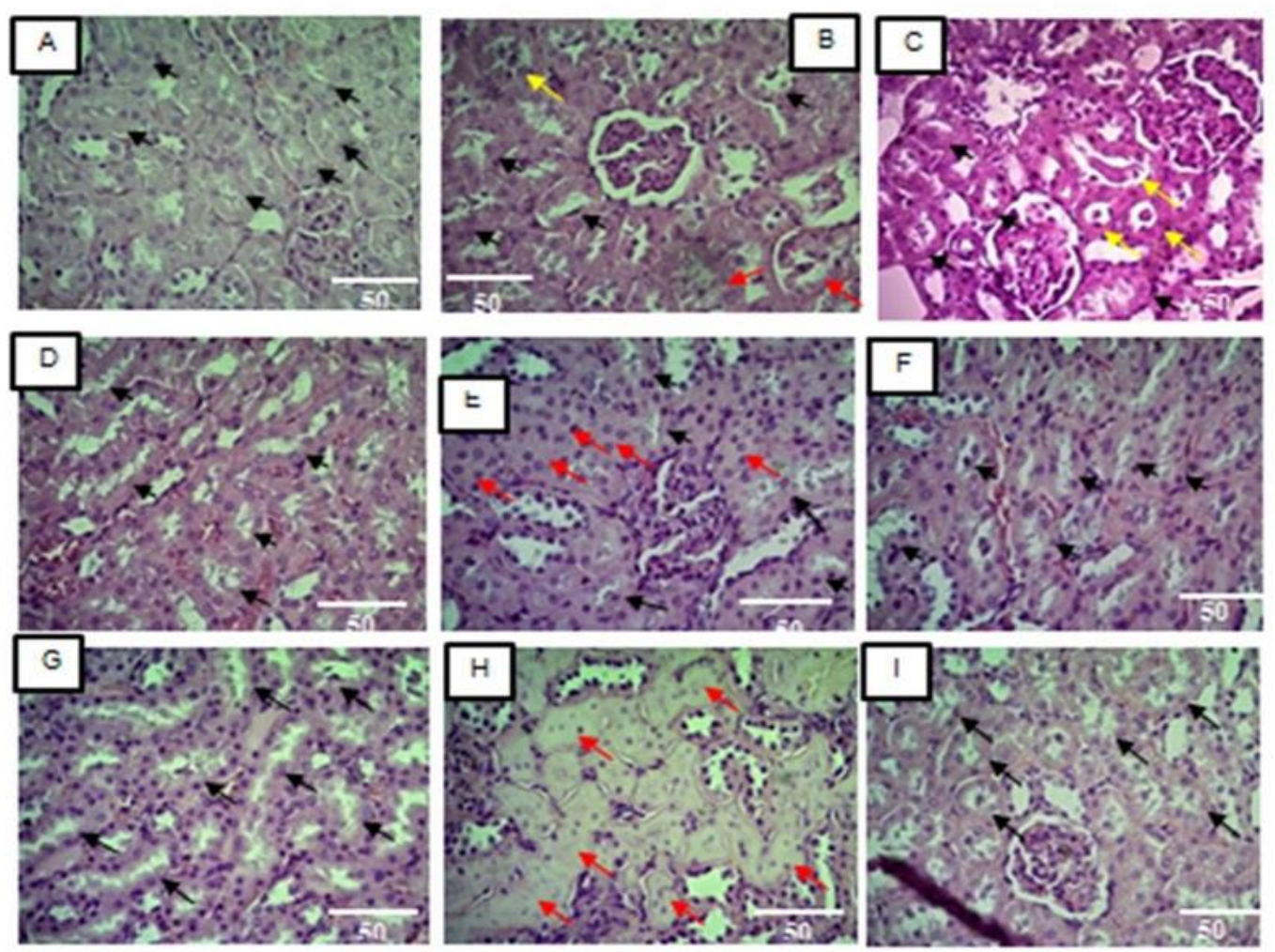

Gambar 4. Hasil pengamatan Mikroskopik Tubulus Proksimal Normal (Panah Hitam) dan ubulus Proksimal rusak (Panah merah dan kuning) Ginjal ikus.(A) Aquadest 1,5 ml/hr selama 28 hari.; (B) Aquadest 1,5 ml/hari selama 42 hari; (C)Aquadest $1,5 \mathrm{ml} /$ hari selama 56 hari; (D) MSG dosis $5 \mathrm{mg} / \mathrm{gBB} /$ hari selama 28 hari; (E) MSG dosis $5 \mathrm{mg} / \mathrm{gBB} /$ Hari selama 42 hari; (F) MSG dosis $5 \mathrm{mg} / \mathrm{gBB} / \mathrm{hari}$ selama 56 hari (G) MSG dosis $5 \mathrm{mg} / \mathrm{gBB} / \mathrm{hari}$ selama 28 hari kemudian dihentikan selama 1 hari; (H) MSG dosis $5 \mathrm{mg} / \mathrm{gBB} /$ hari selama 28 hari kemudian dihentikan selama 14 hari; (I) MSG dosis $5 \mathrm{mg} / \mathrm{gBB} /$ hari selama 28 hari kemudian dihentikan selama 28 hari.Pada tubulus proksimal tampak tubulus yang menyempit (panah merah) dan adanya hyaline cast pada tubulus (panah kuning),HE, Objektif 40x.

Pada gambar diatas tampak bahwa ada perbedaan yang bermakna antar seluruh kelompok kontrol positif dengan kontrol negatif dengan perbedaan signifikansi, Hal ini menandakan terjadi kerusakan korpuskulum ginjal akibat pajanan MSG yang ditandai dengan rerata jumlah korpuskulum rusak kontrol negatif > kontrol positif. Pada kelompok perlakuan, terlihat perbedaan yang bermakna antara rerata jumlah korpuskulum ginjal rusak pada kelompok 14 hari pasca penghentian pajanan MSG dengan kelompok 1 hari pasca penghentian pajanan MSG.

\section{KESIMPULAN}

Pada dua penelitian terjadi Kerusakan tubulus yang menyebabkan terganggunya proses 
rearbsorbsi dan sekresi. Jika proses rearbsorbsi terganggu maka zat yang masih dibutuhkan oleh tubuh tidak dapat diserap kembali oleh tubuh sehingga zat tersebut dapat keluar melalui urin. Dan jika proses sekresi terganggu maka zat zat yang tidak dibutuhkan oleh tubuh tidak dapat dikeluarkan melalui urin sehingga bersifat toksik yang dapat merusak organ ginjal. Penumpukan zat tersebut yang harus kita hindari dan jaga dari awal, jadi alangkah bijaknya jika kita lebih selective dalam memilih makanan tanpa MSG untuk dikonsumsi.

\section{DAFTAR PUSTAKA}

Abu-Taweel GM et al, (2014) Cognitive and biochemical effects of monosodium glutamate and aspartame, administered individually and in combination in male albino mice.

Aulia Candra et al (2015) Gambaran Histologis Korteks Ginjal Tikus (Rattus norvegicus) Pasca Penghentian Pajanan Monosudium Glutamat per Oral Jurnal Cerebellum. Volume 1 Nomor 3. Agustus. Jurnal Cerebellum.
Desy Togatorop et al (2016) Gambaran histologik ginjal tikus Wistar yang diberikan jus tomat setelah diinduksi dengan monosodium glutamat Volume 4, Nomor 2, Juli Desember Jurnal e-Biomedik (eBm)

Eweka et al (2011) - Histochemical Studies of the Effects of Monosodium Glutamate on the Liver of Adult Wistar Rats.

FDA (not updated) (2012) Questions and Answers on Monosodium glutamate (MSG)

Gani, Y dan Munir, W. 1992. Pengaruh tamoxifen terhadap struktur ginjal dan hipofisa mencit (Mus Musculus). Jurnal Matematika dan Pengetahuan Alam 2(1):50.

Guyton, A. C \& Hall, J. E. 2007. Buku Ajar Fisiologi Kedokteran. Edisi 11. Jakarta: Penerbit Buku Kedokteran EGC.

Horvath et al (2013) - Exposure to Enriched Environment Decreases Neurobehavioral Deficits Induced by Neonatal Glutamate Toxicity

Indonesian Renal Registry (IRR).2013.5th Report of Indonesian Renal Registry

Junqueira, L, C \& Carneiro, J. 1991. Histologi Dasar Edisi 3. Jakarta: Penerbit Buku Kedokteran EGC. 
Syaifuddin. 2000. Fungsi Sistem

Tubuh Manusia. Jakarta:

Penerbit Widya Medika: hlm. 218-219.

Sloane, E. 2003. Anatomi dan Fisiologi Untuk Pemula. Jakarta: Penerbit Buku Kedokteran EGC.

Tambajong, J. 1995. Sinopsis Histologi. Jakarta: Penerbit Buku Kedokteran ECG: hlm. 163.
United States Renal Data System. 2014. 2014 USRDS Annual Data Report, Volume 2: EndStage Renal Disease.

World Health Organization. USRDS Anual Data Report. US.2013.

Wibowo, D.S \& Widjaja, P. 2009. Anatomi Tubuh Manusia. Jakarta: Penerbit Graha: hlm. 42. 